Original article

10.2478/aiht-2018-69-3126

\title{
Urban honey - the aspects of its safety
}

\author{
Milica S. Jovetić ${ }^{1}$, Azra S. Redžepović1 ${ }^{1}$ Nebojša M. Nedić², Denis Vojt², Slađana Z. Đurđić \\ Ilija D. Brčeski ${ }^{3}$, and Dušanka M. Milojković-Opsenica ${ }^{3}$
}

\author{
Center for Food Analysis ${ }^{1}$, University of Belgrade Faculty of Agriculture ${ }^{2}$, University of Belgrade Faculty of
} Chemistry3, Belgrade, Serbia

[Received in March 2018; Similarity Check in March 2018; Accepted in June 2018]

To contribute to the development of urban beekeeping, we designed this study to obtain more information about the contamination of urban bee products with toxic metals, polycyclic aromatic hydrocarbons (PAHs), and pesticides. The samples of honey $(\mathrm{N}=23)$, pollen $(\mathrm{N}=13)$, and floral nectar $(\mathrm{N}=6)$ were collected from the experimental stationary apiary of the Belgrade University Faculty of Agriculture located in centre of Zemun (a municipality of the Belgrade metropolitan area) in 2015 and 2016. Metals ( $\mathrm{Pb}, \mathrm{Cd}, \mathrm{As}, \mathrm{Cu}, \mathrm{Zn}, \mathrm{Fe}, \mathrm{Mn}, \mathrm{Ni}, \mathrm{Cr}$, and $\mathrm{Hg}$ ) were determined with inductively coupled plasma quadrupole mass spectrometry (ICP-QMS). Polycyclic aromatic hydrocarbons (PAHs) were analysed with highperformance liquid chromatography with fluorescence detection (HPLC-FLD). Pesticides were analysed with gas chromatography - mass spectrometry (GC-MS). The honey samples were generally within the European and Serbian regulatory limits. The levels of all the 123 analysed pesticides were below the limit of quantification (LOQ). Regarding PAH levels in honey, the highest content was found for naphthalene. The elevated levels of $\mathrm{Hg}$ and $\mathrm{Cr}$ and of PAHs in the pollen samples indicated air pollution. Pesticide residues in pollen, however, were below the LOQ. In nectar, metal levels were relatively similar to those in honey. Our results suggest that the investigated urban honey meets the regulatory requirements for metals, PAHs, and pesticides and is therefore safe for consumption.

KEY WORDS: beekeeping; contaminants; pollen; urban areas

Back in 1901, in his book The Life of the Bee, Maurice Maeterlinck made an interesting point, relevant for all mankind: "If the bee disappeared off the face of the earth, man would only have four years left to live" (1). Bees are efficient and reliable pollinators; they are methodical collectors of nectar and pollen, do not destroy the plant, and maintain the biodiversity and productivity of both natural and agricultural ecosystems (2). They also contribute to human wealth through the production of honey and other products (pollen, wax, propolis, and royal jelly).

In terms of environmental monitoring, bees are excellent mobile samplers and bioindicators of chemical contamination, as they come into contact with a variety of pollutants during their foraging flights (2-4). Contaminants cause high mortality rates of bees and end up in honey and other bee products (5) either indirectly, from the environment or agricultural practice, or directly, from beekeeping practice. The most important environmental contaminants are toxic (heavy) metals, pesticides, polychlorinated biphenyls (PCBs), polycyclic aromatic hydrocarbons (PAHs), bacteria, genetically modified organisms, and radioactivity. Contaminants that originate from inappropriate beekeeping practice include substances used to control bee pests and diseases (acaricides, antibiotics, pesticides, etc.)

Correspondence to: Dušanka Milojković-Opsenica, University of Belgrade Faculty of Chemistry, Studentski trg 12-16, 11158 Belgrade, Serbia, E-mail:dusankam@chem.bg.ac.rs and heavy metals from the honey storage equipment and containers (6-8).

Unfortunately, bees are in decline across the globe. Over the past 10 to 15 years, beekeepers have been reporting unusual drops in bee numbers and colony losses throughout Europe and the USA. Statistics show a devastating $25 \%$ loss of honey bees in Europe since 1985 (45 \% in the UK alone since 2010$)$ and $40 \%$ in the USA since $2006(9,10)$. This phenomenon has been termed colony collapse disorder (CCD) and cannot be attributed to any single cause. The scientific community, however, points to the following possible contributing factors that act in combination or separately: beekeeping practices, environmental factors, chemical factors, and biological agents, which together create stress, weaken the bee's immune system, and pave way for pests and pathogens to kill colonies $(9,11)$.

In view of the ecological and economic importance of bees, this has raised the issue of their monitoring and protection all over the world. In 2011, the European Environmental Agency (EEA) started The Project City Bees on the assumption that bees were less exposed to pesticides in the cities $(12,13)$. The consequent assumption is that honey produced in the cities would be free from impurities, especially as the bees filter the nectar. However, there are too few (or too narrow) reports on the quality and the safety of honey produced exclusively in the cities to either refute or support it. 
The main aim of this study was, therefore, to obtain, for the first time, a more comprehensive information about the contamination of the so-called urban honey with toxic metals, polycyclic aromatic hydrocarbons (PAHs), and pesticide residues. Beside the honey, we analysed pollen and floral nectar to better understand the impact of urban environment on their safety aspects.

Another aim was to compare our findings with the relevant regulations. The EU has set maximum residue levels (MRLs) for a wide spectra of pesticides with its EC Regulation No. 396/2005 (14) and for pharmacologically active substances in honey with the Regulation No. 37/2010 (15). Serbia has also set MRLs for pesticides in honey (16). As for heavy metals, the EU regulations define the maximum level (ML) of lead alone, while Serbian regulations have also included cadmium, arsenic, zinc, copper, and iron in honey $(16,17)$. However, no MLs for PAHs in honey and other bee products have yet been established. Even so, their presence could certainly impair the safety of honey and in the city area they mostly reflect contamination from traffic and combustion of fossil fuels, which are still used for heating in many households in Zemun.

The idea to investigate urban honey came from an earlier collaboration with the Serbian Federation of Beekeeping Associations (SPOS, in which we analysed 379 monofloral and polyfloral honeys from all over Serbia for their physicochemical parameters (including metal content). Having found that heavy metal content, cadmium, for example, did not exceed the Serbian limits (18), we wanted to broaden our research.

\section{MATERIALS AND METHODS}

\section{Sample collection}

Samples for this study were obtained from an experimental stationary apiary located in the centre of Zemun, a municipality belonging to the Belgrade metropolitan area. The samples were collected by trained personnel of the Belgrade University Faculty of Agriculture. The bee colonies were kept in standard Langstoth's type beehive with 10 frames. The apiary had been monitored by the experts of the same institution to exclude any contamination caused by beekeeping, such as inadequate beehive treatment or equipment, and limit contamination to environmental sources.

We collected 23 samples of unprocessed polyfloral honey (16 in 2015 and seven in 2016) and 13 samples of bee pollen (10 in 2015 and three in 2016 year) taking care that honey and pollen samples corresponded to each other by collecting them at the same time. Honey samples were taken with $20 \mathrm{~mL}$ sterile syringes from parts of a young honeycomb that did not come into contact with the supporting wire. During collection, we did not use smoke.
Pollen samples were collected by placing plastic pollen collectors (pollen catching traps) at the entrance to the beehive. We also took six samples of nectar in 2016 by extracting it from the foragers' honey stomachs. Table 1 gives an overview of the collected samples.

Honey and pollen samples were stored in polyethylene containers (Lab Logistics Group GmbH, Meckenheim, Germany) suitable for foodstuff according to the EC

Table 1 The overview of the analysed samples of honey, bee pollen and nectar

\begin{tabular}{|c|c|}
\hline Sample & Description \\
\hline h1 & honey, April 2015 \\
\hline h2 & honey, April 2015 \\
\hline h3 & honey, April 2015 \\
\hline h4 & honey, April 2015 \\
\hline h5 & honey, May 2015 \\
\hline h6 & honey, May 2015 \\
\hline h7 & honey, May 2015 \\
\hline $\mathrm{h} 8$ & honey, May 2015 \\
\hline h9 & honey, June 2015 \\
\hline h10 & honey, June 2015 \\
\hline h11 & honey, July 2015 \\
\hline $\mathrm{h} 12$ & honey, July 2015 \\
\hline h13 & honey, July 2015 \\
\hline h14 & honey, July 2015 \\
\hline h15 & honey, August 2015 \\
\hline h16 & honey, August 2015 \\
\hline h17 & honey, April 2016 \\
\hline h18 & honey, April 2016 \\
\hline h19 & honey, June 2016 \\
\hline $\mathrm{h} 20$ & honey, June 2016 \\
\hline h21 & honey, June 2016 \\
\hline h22 & honey, June 2016 \\
\hline $\mathrm{h} 23$ & honey, October 2016 \\
\hline p1 & pollen, April 2015 \\
\hline p2 & pollen, April 2015 \\
\hline p3 & pollen, May 2015 \\
\hline $\mathrm{p} 4$ & pollen, May 2015 \\
\hline p5 & pollen, May 2015 \\
\hline p6 & pollen, May 2015 \\
\hline p7 & pollen, June 2015 \\
\hline $\mathrm{p} 8$ & pollen, June 2015 \\
\hline p9 & pollen, July 2015 \\
\hline p10 & pollen, July 2015 \\
\hline p11 & pollen, April 2016 \\
\hline p12 & pollen, June 2016 \\
\hline p13 & pollen October 2016 \\
\hline $\mathrm{n} 1$ & nectar, April 2016 \\
\hline $\mathrm{n} 2$ & nectar, April 2016 \\
\hline n3 & nectar, June 2016 \\
\hline $\mathrm{n} 4$ & nectar, June 2016 \\
\hline n5 & nectar, June 2016 \\
\hline n6 & nectar, June 2016 \\
\hline
\end{tabular}


Regulations No. 1935/2004 and 10/2011 (19, 20). Honey samples were kept at room temperature, in the dark. Pollen samples were stored in a refrigerator at $4-8{ }^{\circ} \mathrm{C}$. Nectar samples were stored in safe-lock tubes (Eppendorf $\mathrm{AG}$, Hamburg, Germany) and deep-frozen at $-18{ }^{\circ} \mathrm{C}$ until analysis. The pollen grains were powdered with a pestle in a mortar for homogeneity just before analysis.

\section{Chemicals and materials}

All chemicals were of analytical grade and supplied by Merck (Darmstadt, Germany): nitric acid 65\% (for analysis EMSURE $^{\circledR}$ ISO), hydrogen peroxide $30 \%$ (for analysis EMSURE $^{\circledR}$ ISO) and acetonitrile $\geq 99.9 \%\left(\right.$ LiChrosolv $\left.^{\circledR}\right)$. The QuEChERS kits for PAHs with salt packets containing $4 \mathrm{~g}$ of anhydrous magnesium sulphate $\left(\mathrm{MgSO}_{4}\right)$ and $0.5 \mathrm{~g}$ of sodium chloride $(\mathrm{NaCl})$, the QuEChERS kits for pesticides with salt packets containing $4 \mathrm{~g} \mathrm{MgSO}_{4}, 1 \mathrm{~g} \mathrm{NaCl}$, $1 \mathrm{~g}$ trisodium citrate dihydrate, and $0.5 \mathrm{~g}$ disodium hydrogen citrate sesquihydrate, and $6 \mathrm{~mL}$ centrifuge tubes with $900 \mathrm{mg}$ anhydrous $\mathrm{MgSO}_{4}, 150 \mathrm{mg}$ of primary secondary amine (PSA), and $150 \mathrm{mg}$ octadecylsilane (ODS, also known as C18) for dispersive solid-phase extraction (dSPE) were purchased from Restek (Bellefonte PA, USA).

Deionised water (electrical resistivity $18.2 \mathrm{M} \Omega \mathrm{cm}^{-1}$ ) was obtained using the Simplicity ${ }^{\circledR}$ water purification system (Merck Millipore, Burlington MA, USA).

For the quantification of metals, we used multi-element stock solution $\left(1,000 \mathrm{~g} \mathrm{~L}^{-1}\right.$ of trace elements, Merck, Germany) to prepare intermediate multi-element standard solutions. Instead of certified reference materials, we used the leftover of the test material from the Fapas proficiency testing "Metallic contaminants in honey" (07286, Fapas, London, UK) for quality control of the analytical procedure.

For PAH analysis standard we used the PAH mix 16 (100 mg L ${ }^{-1}$ ) from Neochema (Bodenheim, Germany).

For pesticide residue analysis we used the following multiresidue pesticide standards: Organochlorine Pesticide Mix AB\#3, 531.2 Carbamate Pesticide Cal Mix, Minnesota Ag List 1 Pesticides Mix A, 527 Pesticide Calibration Standard \#1, 8140/8141 OP Pesticide Calibration Mix A (all by Restek), Pesticide Mix E27, Pesticide Mix F30, and Pesticide Mix E30 (all by Lab Standards, Castellana Grotte, Italy) as well as single residue pesticide standards: biphenyl and prothioconazole-desthio by Sigma-Aldrich, (Taufkirchen, Germany), fipronil-sulphone by Lab Standards, and burpofezin, dimethomorph, diphenylamine, fenamidone, fenhexamid, ipodione, terbuthylazine, and tetramethrin by Dr. Ehrenstorfer GmbH (Augsburg, Germany). The analytical-grade solution of triphenyl phosphate (TPP), used as internal standard in pesticide analysis, was purchased from Restek.

\section{Metal analysis}

Test portions of about $0.5 \mathrm{~g}$ of honey, $0.3 \mathrm{~g}$ of pollen and $0.4-0.5 \mathrm{~g}$ of nectar were treated with $7 \mathrm{~mL}$ of nitric acid and $2 \mathrm{~mL}$ of hydrogen peroxide in polytetrafluoroethylene (PTFE) vessels and then mineralised in a microwave closed digestion system (Ethos Touch, Milestone, Bergamo, Italy) by heating up to $180{ }^{\circ} \mathrm{C}$ for $15 \mathrm{~min}$, followed by heating up to $220^{\circ} \mathrm{C}$ for $15 \mathrm{~min}$, and then heating up to $240^{\circ} \mathrm{C}$ for $10 \mathrm{~min}$. After digestion, honey and pollen samples were quantitatively transferred into $50 \mathrm{~mL}$ volumetric flasks and diluted with deionised water. The digested samples of nectar were transferred into $25 \mathrm{~mL}$ volumetric flasks and also diluted with deionised water.

Trace element ( $\mathrm{Pb}, \mathrm{Cd}, \mathrm{As}, \mathrm{Cu}, \mathrm{Zn}, \mathrm{Fe}, \mathrm{Mn}, \mathrm{Ni}, \mathrm{Cr}$, and $\mathrm{Hg}$ ) levels were determined with inductively coupled plasma quadrupole mass spectrometry (ICP-QMS) (iCAP Q, Thermo Scientific X series 2, Waltham MA, USA). The entire system was controlled with the Qtegra Instrument Control Software (Thermo Scientific, Waltham, MA, USA). Instrumental conditions were as follows: Rf power $1548 \mathrm{~W}$; gas flows: $13.9,1.09,0.8 \mathrm{~L} \mathrm{~min}^{-1}$; acquisition time: $3 \times 50 \mathrm{~s}$; points per peak: 3 ; dwell time: $10 \mathrm{ns;} \mathrm{detector} \mathrm{mode:} \mathrm{pulse.}$ The measured isotopes were: ${ }^{50} \mathrm{Cr},{ }^{55} \mathrm{Mn},{ }^{57} \mathrm{Fe},{ }^{60} \mathrm{Ni},{ }^{65} \mathrm{Cu}$, ${ }^{68} \mathrm{Zn},{ }^{75} \mathrm{As},{ }^{111} \mathrm{Cd},{ }^{202} \mathrm{Hg}$, and ${ }^{208} \mathrm{~Pb}$.

\section{PAH analysis}

As we mentioned earlier, there are no MLs for PAHs in honey, but we decided to analyse 15 of the 16 PAHs frequently found in environmental monitoring samples (according to the United States Environmental Protection Agency): acenaphtene, anthracene, benzo[a]anthracene, benzo[a]pyrene, benzo[b]fluoranthene, benzo[g,h,i] perylene, benzo[k]fluoranthene, chrysene, dibenzo[a,h] anthracene, fluoranthene, fluorine, indeno[1.2.3-cd]pyrene, naphthalene, phenanthrene, pyrene, and their sum.

Samples of $5 \pm 0.1 \mathrm{~g}$ honey and $2 \pm 0.1 \mathrm{~g}$ pollen were weighed into a $50 \mathrm{~mL}$ polypropylene centrifuge tube and added $10 \mathrm{~mL}$ of deionised water. After $30 \mathrm{~min}, 10 \mathrm{~mL}$ of acetonitrile was added and the tube hand-shaken for $1 \mathrm{~min}$. As soon as the QuEChERS salt kit for PAHs was added the sample was hand-shaken again for $1 \mathrm{~min}$ and then centrifuged at $1507 \mathrm{~g}$ for $5 \mathrm{~min}$. Then $6 \mathrm{~mL}$ of the acetonitrile fraction was transferred into a $6 \mathrm{~mL} \mathrm{dSPE}$ polypropylene tube. The tube was hand-shaken for $1 \mathrm{~min}$ and centrifuged at $1507 \mathrm{~g}$ for $5 \mathrm{~min}$. Five $\mathrm{mL}$ of the clear solution was transferred into a $15 \mathrm{~mL}$ glass tube, and the eluate was evaporated to dryness at $60{ }^{\circ} \mathrm{C}$ using a gentle stream of nitrogen. The residues were dissolved in $1 \mathrm{~mL}$ of acetonitrile. Extracts of the samples in acetonitrile were passed through a $0.45 \mu \mathrm{m}$ nylon membrane filter and analysed with a Thermo Spectra System (Thermo Scientific) high-performance liquid chromatographer with fluorescence detection (HPLC-FLD) equipped with the FL2000/FL3000 ULTRAFLUOR fluorescence detector and ChromQuest 4.2.35 software (Thermo Scientific) by injecting $50 \mu \mathrm{L}$ of the sample into the Agilent Zorbax Eclipse PAH C18 column ( $4.6 \times 250 \mathrm{~mm}$; i.d. $5 \mathrm{~mm}$, Agilent, Santa Clara CA, USA). The column temperature was ambiental $\left(25^{\circ} \mathrm{C}\right)$; 
mobile phase A (water) and B (acetonitrile). The gradient elution was programmed as follows: $50 \% \mathrm{~B}$ (0-0.7 min) with $1.5 \mathrm{~mL} \mathrm{~min}^{-1}$ flow rate; $50 \% \mathrm{~B}$ to $75 \% \mathrm{~B}$ linearly (0.7-12 min) with $2.0 \mathrm{~mL} \mathrm{~min}^{-1}$ flow rate; $100 \% \mathrm{~B}(12-$ $25 \mathrm{~min}$ ) with $2.0 \mathrm{~mL} \mathrm{~min}^{-1}$ flow rate; and $100 \% \mathrm{~B}$ to $50 \%$ B linearly (25-30 min) with $1.5 \mathrm{~mL} \mathrm{~min}^{-1}$ flow rate. For quantification we used the external standard method.

\section{Pesticide analysis}

Samples of $5 \pm 0.1 \mathrm{~g}$ honey and $2 \pm 0.1 \mathrm{~g}$ of pollen were weighed into a $50 \mathrm{~mL}$ polypropylene centrifuge tube and added $10 \mathrm{~mL}$ of deionised water and $50 \mu \mathrm{L}$ of internal standard solution (TPP at $20 \mu \mathrm{g} \mathrm{mL} \mathrm{m}^{-1}$ ). After $30 \mathrm{~min}, 10 \mathrm{~mL}$ of acetonitrile was added, the tube was hand-shaken for $1 \mathrm{~min}$. As soon as the QuEChERS salt kit for pesticides was added the sample hand-shaken again for $1 \mathrm{~min}$ and then centrifuged at $1507 \mathrm{~g}$ for $5 \mathrm{~min}$. Then $6 \mathrm{~mL}$ of the acetonitrile fraction was transferred into a $6 \mathrm{~mL}$ dSPE polypropylene tube. The tube was hand-shaken for $1 \mathrm{~min}$ and centrifuged at $1507 \mathrm{~g}$ for $5 \mathrm{~min}$. Five $\mathrm{mL}$ of the clear solution was transferred into a $15 \mathrm{~mL}$ glass tube, and the eluate was evaporated to dryness at $60{ }^{\circ} \mathrm{C}$ using a gentle stream of nitrogen. The residues were dissolved in $1 \mathrm{~mL}$ acetonitrile, and $1 \mu \mathrm{L}$ of the sample was injected into a HP-5MS UI $0.25 \mu \mathrm{m}, 0.25 \mathrm{~mm} \times 30 \mathrm{~m}$ column for gas chromatography mass spectrometry (GC-MS) a 7890A GC system, a 5975C MS system, and a 7683B autosampler (Agilent Technologies). The column was set to constant pressure. The injector temperature was $250^{\circ} \mathrm{C}$, and samples were injected in the splitless mode (the split vent opened after $30 \mathrm{~s}$ ). The column temperature was programmed as follows: the initial temperature started at $70^{\circ} \mathrm{C}$ (for $2 \mathrm{~min}$ ), increased to $150{ }^{\circ} \mathrm{C}$ at the rate of $25{ }^{\circ} \mathrm{C} \mathrm{min}{ }^{-1}$, then immediately increased to $200^{\circ} \mathrm{C}$ at $3{ }^{\circ} \mathrm{C} \mathrm{min}^{-1}$, and ramped to $280^{\circ} \mathrm{C}$ at $8^{\circ} \mathrm{C} \mathrm{min}^{-1}$ (held for $10 \mathrm{~min}$ ). The total run time was $41.87 \mathrm{~min}$. The MS ionisation potential was $70 \mathrm{eV}$, and the temperatures were as follows: ion source $230{ }^{\circ} \mathrm{C}$, transfer line $280{ }^{\circ} \mathrm{C}$, and analyser $150{ }^{\circ} \mathrm{C}$. The mass spectrometer was operated in the scan and selected-ion monitoring (SIM) mode.

\section{Quality parameters of honey}

Beside the metal content, PAHs, and pesticide residues, the honey samples were analysed for quality according to Harmonised Methods of the International Honey Commission (IHC) (21).

\section{RESULTS AND DISCUSSION}

Our samples of urban honey met the basic physicochemical requirements for good quality, which supports the recent report on honey from stationary apiaries located in Serbian cities (22).

\section{Heavy metal content}

Table 2 shows the content of $\mathrm{Pb}, \mathrm{Cd}, \mathrm{As}, \mathrm{Cu}, \mathrm{Zn}$, and $\mathrm{Fe}$ and the corresponding Serbian MLs (16) in honey samples. Except for $\mathrm{Cu}$, all the urban honey samples met the requirements of the Serbian regulations, even though several studies warned about higher $\mathrm{Pb}$ in urban honey from polluted areas near busy roads and railways $(5,23)$. They ranged from $<0.003$ to $0.085 \mathrm{mg} \mathrm{kg}^{-1}$ in 2015 and from $<0.003$ to $0.107 \mathrm{mg} \mathrm{kg}^{-1}$ in 2016. Similarly, Cd and As levels kept very low in both years, whereas reports for Croatian honey were higher and ranged from 0.001 to $0.024 \mathrm{mg} \mathrm{kg}^{-1}$ for Cd and 0.004-0.105 mg kg-1 for As (24).

The levels of $\mathrm{Cu}, \mathrm{Zn}, \mathrm{Fe}, \mathrm{Mn}, \mathrm{Ni}$ and $\mathrm{Cr}$ were scattered even in samples from the same month. This variation, especially of $\mathrm{Cu}$, which exceeded the MLs in four samples, was most likely related to the diversity of the foraged plant species, but some of it may be owed to the presence of pollen particles, because the sampled honey was unprocessed. The content of $\mathrm{Mn}$ and $\mathrm{Ni}$ was similar to the one reported in Romanian honey $\left(0.868-2.529 \mathrm{mg} \mathrm{kg}^{-1}\right.$ for $\mathrm{Mn}$ and $0.122-0.325 \mathrm{mg} \mathrm{kg}^{-1}$ for $\mathrm{Ni}$ ), while $\mathrm{Cr}$ content was significantly higher $\left(0.029-0.051 \mathrm{mg} \mathrm{kg}^{-1}\right)(25)$.

Data about mercury content in urban honey are scarce. Our results correspond to those reported in areas affected with industrial pollution in Slovakia, where it ranged from 0.050 to $0.212 \mathrm{mg} \mathrm{kg}^{-1}$ (26). Small amounts of mercury $\left(0.083 \pm 0.011 \mu \mathrm{g} \mathrm{kg}^{-1}\right.$ of dry matter $)$ were also found in honey samples from apiaries located in the area of the University of Veterinary Medicine and Pharmacy in Košice, also in Slovakia (27). In Greek honey from both rural and industrialised areas mercury content was lower than $0.05 \mathrm{mg} \mathrm{kg}^{-1}$ (28).

As there are no regulations for metal content in bee pollen, we can only compare our findings (Table 2, p1-p13) with similar recent studies, particularly those investigating pollen from urban areas. Average $\mathrm{Pb}$ and $\mathrm{Cd}$ contents $(0.17$ $\mathrm{mg} \mathrm{kg}^{-1}$ and $0.05 \mathrm{mg} \mathrm{kg}^{-1}$, respectively) were similar to those reported for Polish pollen from stationary apiaries located in an industrial area (29). On the other hand, Cd content in bee pollen obtained in this study corresponds well to those reported earlier in samples not only from the Belgrade surroundings but also from non-urban parts of Serbia (30). The same is true for the content of $\mathrm{Cu}, \mathrm{Zn}, \mathrm{Fe}, \mathrm{Mn}$ and $\mathrm{Ni}$.

In 2015, Hg levels ranged from 0.073 to $0.198 \mathrm{mg} \mathrm{kg}^{-1}$ in 2015, while in 2016 they were higher and ranged from 0.128 to $0.519 \mathrm{mg} \mathrm{kg}^{-1}$. The Slovakian study of bee pollen from the apiaries in Košice (27) reported lower Hg levels $\left(0.05134 \pm 0.000038 \mathrm{mg} \mathrm{kg}^{-1}\right.$ of dry matter), and so did the Greek study $\left(<0.06 \mathrm{mg} \mathrm{kg}^{-1}\right)$ (28). The elevated $\mathrm{Hg}$ levels in our study may be attributed to different anthropogenic activities, especially combustion of fossil fuels containing toxic metals at trace levels (26), which are still used for heating in many households of Zemun and its surroundings.

Cr levels ranged from 2.474 to $5.998 \mathrm{mg} \mathrm{kg}^{-1}$ and were significantly higher than those reported for Polish (29) and 
Table 2 Metal concentrations in honey (h), bee pollen (p), and nectar (n) samples collected in 2015-2016

\begin{tabular}{|c|c|c|c|c|c|c|c|c|c|c|}
\hline \multirow[t]{2}{*}{ Samples } & \multicolumn{10}{|c|}{$\begin{array}{l}\text { Metals } \\
\left(\mathrm{mg} \mathrm{kg}^{-1}\right)\end{array}$} \\
\hline & $\mathbf{P b}$ & Cd & As & $\mathrm{Cu}$ & Zn & $\mathrm{Fe}$ & Hg & Mn & $\mathbf{N i}$ & $\mathrm{Cr}$ \\
\hline h1 & 0.004 & $<0.002$ & $<0.001$ & 0.532 & 1.804 & 3.721 & 0.082 & 0.847 & 0.406 & 0.149 \\
\hline h2 & 0.015 & 0.002 & $<0.001$ & $<0.015$ & 1.319 & 3.534 & 0.078 & 1.241 & 0.071 & $<0.005$ \\
\hline h3 & $<0.003$ & $<0.002$ & 0.004 & 0.398 & 1.203 & 3.762 & 0.062 & 0.837 & 0.203 & 0.137 \\
\hline h4 & 0.033 & 0.002 & 0.001 & 0.531 & 1.635 & 5.581 & 0.174 & 1.113 & 0.203 & 0.094 \\
\hline h5 & 0.016 & 0.003 & 0.001 & 0.497 & 1.301 & 3.730 & 0.102 & 0.792 & 0.157 & $<0.005$ \\
\hline h6 & 0.042 & $<0.002$ & $<0.001$ & $<0.015$ & 2.311 & 2.753 & 0.085 & 0.839 & 0.093 & 0.322 \\
\hline h7 & 0.085 & $<0.002$ & $<0.001$ & $<0.015$ & 0.008 & 1.981 & 0.257 & 0.079 & $<0.010$ & 0.018 \\
\hline h8 & $<0.003$ & $<0.002$ & $<0.001$ & $<0.015$ & 0.290 & 7.339 & 0.036 & 0.186 & 0.017 & 0.367 \\
\hline h9 & 0.011 & $<0.002$ & $<0.001$ & $<0.015$ & 1.022 & 3.721 & 0.048 & 0.380 & 0.029 & 0.090 \\
\hline h10 & 0.020 & $<0.002$ & $<0.001$ & $<0.015$ & $<0.002$ & 1.420 & 0.096 & 0.136 & 0.050 & 0.535 \\
\hline h11 & 0.048 & 0.004 & 0.005 & 0.790 & 3.456 & 7.843 & 0.034 & 0.798 & 0.079 & 0.118 \\
\hline h12 & 0.033 & 0.005 & 0.009 & 1.362 & 1.121 & 5.142 & 0.072 & 1.590 & 0.261 & 0.173 \\
\hline h13 & 0.028 & $<0.002$ & $<0.001$ & 0.478 & $<0.002$ & 6.225 & 0.019 & 0.904 & 0.182 & 0.379 \\
\hline h14 & 0.038 & 0.004 & 0.006 & 1.158 & 1.418 & 6.786 & $<0.002$ & 0.999 & 0.134 & 0.120 \\
\hline h15 & 0.015 & 0.008 & 0.002 & 1.425 & 1.367 & 6.042 & 0.013 & 0.904 & 0.344 & 0.065 \\
\hline h16 & 0.017 & 0.002 & 0.001 & 0.937 & 1.042 & 4.423 & 0.012 & 0.872 & 0.169 & 0.008 \\
\hline h17 & 0.007 & 0.002 & $<0.001$ & $<0.015$ & 0.427 & $<0.012$ & $<0.002$ & 0.787 & 0.162 & 0.755 \\
\hline h18 & $<0.003$ & 0.005 & $<0.001$ & 0.167 & 1.257 & $<0.012$ & $<0.002$ & 0.838 & 0.404 & 0.319 \\
\hline h19 & $<0.003$ & $<0.002$ & $<0.001$ & $<0.015$ & $<0.002$ & 1.119 & $<0.002$ & 0.405 & $<0.010$ & 0.833 \\
\hline h20 & 0.107 & $<0.002$ & $<0.001$ & $<0.015$ & 0.723 & $<0.012$ & $<0.002$ & 0.817 & 0.091 & 0.439 \\
\hline h21 & 0.045 & $<0.002$ & $<0.001$ & 0.644 & 4.346 & 5.247 & $<0.002$ & 1.475 & 0.263 & 0.275 \\
\hline h22 & 0.032 & $<0.002$ & $<0.001$ & $<0.015$ & 0.574 & 2.810 & $<0.002$ & 0.645 & 0.022 & 0.005 \\
\hline h23 & 0.083 & 0.009 & $<0.001$ & 1.781 & 1.381 & 10.054 & $<0.002$ & 2.428 & 0.538 & 0.342 \\
\hline MLs & 0.50 & 0.03 & 0.50 & 1.0 & 10.0 & 20.0 & - & - & - & - \\
\hline p1 & 0.164 & 0.162 & $<0.003$ & 2.587 & 24.95 & 113.83 & 0.198 & 17.14 & 0.613 & 5.998 \\
\hline p2 & 0.132 & 0.097 & $<0.003$ & 3.106 & 29.52 & 107.98 & 0.155 & 19.34 & 0.326 & 4.898 \\
\hline p3 & 0.167 & 0.006 & $<0.003$ & 16.89 & 33.54 & 89.03 & 0.151 & 27.24 & 2.258 & 5.787 \\
\hline p4 & 0.051 & 0.040 & $<0.003$ & 5.348 & 27.22 & 68.32 & 0.123 & 20.69 & 0.634 & 3.917 \\
\hline p5 & 0.073 & 0.041 & $<0.003$ & 4.527 & 30.74 & 71.43 & 0.118 & 24.12 & 0.217 & 2.474 \\
\hline p6 & 0.370 & 0.032 & $<0.003$ & 4.847 & 26.76 & 64.90 & 0.128 & 22.07 & 0.154 & 3.757 \\
\hline p7 & 0.058 & 0.008 & $<0.003$ & 4.849 & 26.18 & 65.01 & 0.073 & 23.00 & 0.554 & 2.749 \\
\hline p8 & 0.057 & 0.025 & $<0.003$ & 4.171 & 29.56 & 63.46 & 0.093 & 18.50 & 0.565 & 3.395 \\
\hline p9 & 0.138 & 0.015 & $<0.003$ & 23.08 & 30.76 & 94.37 & 0.083 & 22.30 & 1.867 & 5.767 \\
\hline p10 & 0.151 & 0.024 & $<0.003$ & 30.67 & 33.64 & 102.39 & 0.051 & 26.05 & 2.773 & 4.103 \\
\hline p11 & 0.686 & 0.118 & $<0.003$ & 13.482 & 32.53 & 106.86 & 0.519 & 23.67 & 1.770 & 3.335 \\
\hline p12 & 0.091 & 0.010 & $<0.003$ & 8.101 & 39.24 & 97.33 & 0.206 & 21.37 & 1.870 & 3.370 \\
\hline p13 & 0.079 & 0.127 & $<0.003$ & 4.023 & 23.14 & 91.80 & 0.128 & 15.43 & 0.240 & 3.083 \\
\hline n1 & 0.059 & 0.002 & 0.134 & $<0.150$ & $<0.012$ & 1.010 & 0.061 & 1.242 & 0.296 & 0.380 \\
\hline n2 & 0.062 & 0.003 & 0.029 & 0.296 & $<0.012$ & 0.189 & 0.098 & 0.844 & 0.094 & 0.585 \\
\hline n3 & 0.052 & 0.003 & 0.004 & 1.318 & $<0.012$ & 5.769 & 0.022 & 1.489 & 0.299 & 1.138 \\
\hline n4 & 0.117 & 0.008 & $<0.003$ & 2.227 & $<0.012$ & 6.117 & 0.023 & 1.942 & 1.075 & 0.351 \\
\hline n5 & $<0.021$ & 0.004 & $<0.003$ & $<0.150$ & $<0.012$ & 2.876 & 0.025 & 0.362 & $<0.009$ & 0.450 \\
\hline n6 & 0.039 & $<0.002$ & $<0.003$ & $<0.150$ & $<0.012$ & 0.569 & $<0.018$ & 0.540 & $<0.009$ & 0.408 \\
\hline
\end{tabular}

Note: bolded figures exceed the Serbian maximum levels (MLs) for honey (16) 


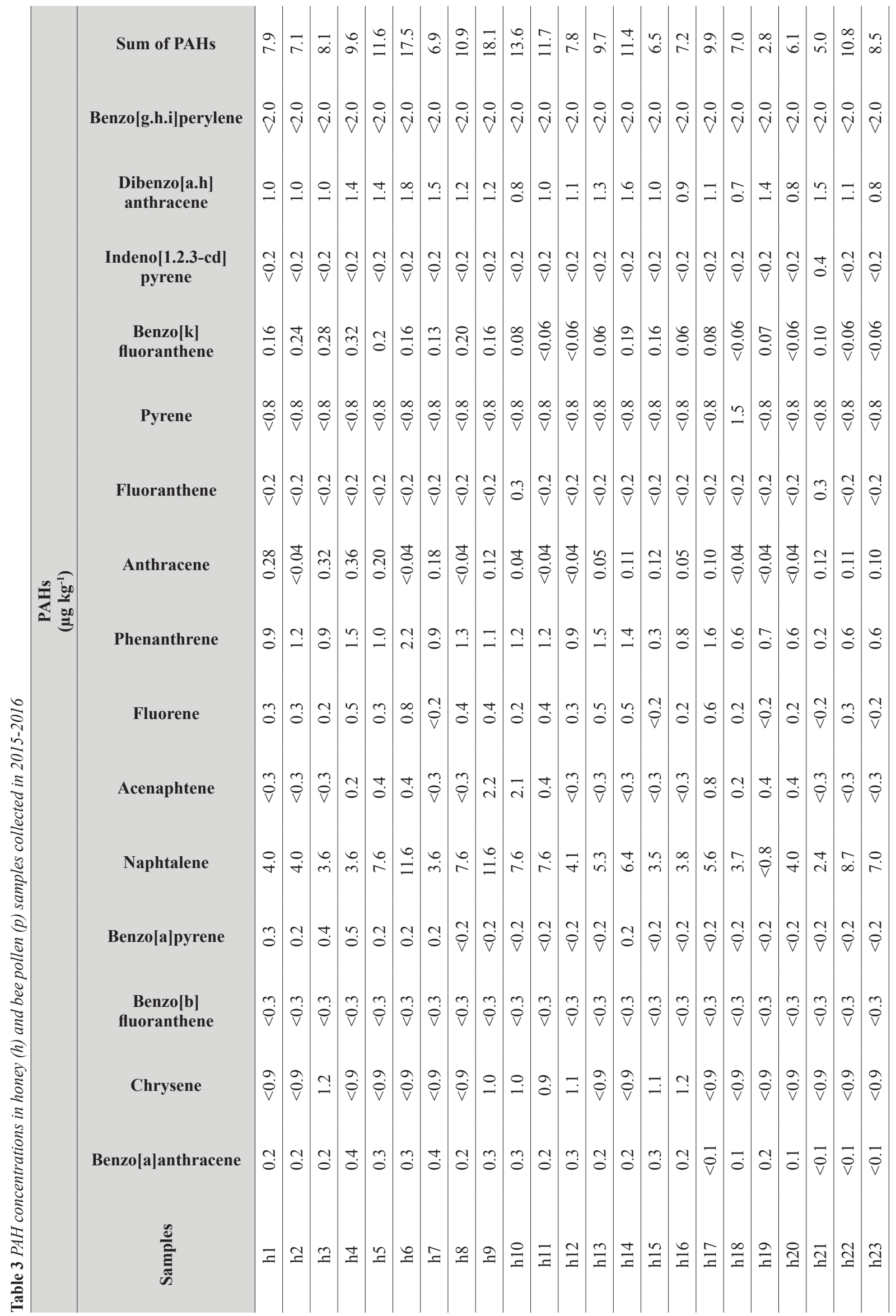




\begin{tabular}{|c|c|c|c|c|c|c|c|c|c|c|c|c|c|c|c|c|}
\hline & Sum of PAHs & $\stackrel{\infty}{i=}$ & 帒 & $\stackrel{n}{m}$ & $\stackrel{\sim}{\sim}$ & 苞 & $\stackrel{0}{0}$ & ֻ̃ & $m$ & 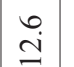 & $\overrightarrow{0}$ & $\stackrel{n}{n}$ & $\vec{i}$ & $\stackrel{\rho}{\dot{y}}$ & $\stackrel{m}{3}$ & $+\frac{m}{6}$ \\
\hline & Benzo[g.h.i]perylene & $\stackrel{\leftrightarrow}{\mathrm{V}}$ & $\dot{v}$ & $\dot{\vec{v}}$ & $\dot{\vec{v}}$ & $\ddot{v}$ & $\ddot{v}$ & $\dot{\vec{v}}$ & $\dot{\vec{v}}$ & $\stackrel{0}{v}$ & $\dot{\vec{v}}$ & $\dot{\ddot{v}}$ & $\begin{array}{l}\dot{v} \\
\dot{v}\end{array}$ & $\dot{v}$ & $\dot{v}$ & $\ddot{v}$ \\
\hline & $\begin{array}{l}\text { Dibenzo[a.h] } \\
\text { anthracene }\end{array}$ & $\frac{\infty}{i}$ & $\stackrel{\infty}{\dot{\vec{v}}}$ & $\stackrel{\infty}{\dot{\vec{v}}}$ & $\stackrel{\infty}{\dot{\varphi}}$ & $\begin{array}{l}\infty \\
\dot{\theta} \\
V\end{array}$ & $\stackrel{\infty}{\dot{v}}$ & $\stackrel{\infty}{\dot{v}}$ & $\stackrel{\infty}{\dot{v}}$ & $\stackrel{\infty}{\dot{v}}$ & $\stackrel{\infty}{\dot{v}}$ & $\stackrel{\infty}{\stackrel{0}{V}}$ & $\stackrel{\infty}{\stackrel{0}{V}}$ & $\vec{i}$ & $\stackrel{\circ}{-}$ & 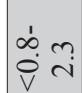 \\
\hline & $\begin{array}{c}\text { Indeno }[1.2 .3-\mathrm{cd}] \\
\text { pyrene }\end{array}$ & 仓ें & $\stackrel{+}{\dot{v}}$ & $\stackrel{\dot{v}}{\vec{v}}$ & $\stackrel{\vec{v}}{\mathrm{v}}$ & $\stackrel{+}{\dot{v}}$ & $\stackrel{t}{\dot{v}}$ & $\frac{\circ}{m}$ & $\stackrel{\vec{F}}{F}$ & $\stackrel{t}{\dot{v}}$ & $\dot{0}$ & $\stackrel{0}{i}$ & $\stackrel{t}{\dot{\sigma}}$ & $\vec{n}$ & $\vec{n}$ & 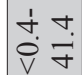 \\
\hline & $\begin{array}{l}\text { Benzo[k] } \\
\text { fluoranthene }\end{array}$ & के & $\stackrel{\sim}{\tilde{V}}$ & $\stackrel{\infty}{-}$ & $\stackrel{0}{0}$ & $\stackrel{\tilde{Q}}{\mathrm{v}}$ & $\stackrel{m}{0}$ & $\dot{m}$ & in & $\tilde{0}$ & $\because$ & ָै & ֻै & $\vec{i}$ & $\ddot{0}$ & 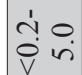 \\
\hline & Pyrene & 年 & $\stackrel{\circ}{i}$ & $\stackrel{\circ}{i}$ & $\stackrel{\circ}{i}$ & $\stackrel{\leftrightarrow}{i}$ & $\stackrel{\leftrightarrow}{i}$ & $\stackrel{i}{i}$ & $\stackrel{i}{i}$ & ì & $\stackrel{0}{0}$ & $\stackrel{0}{\stackrel{1}{r}}$ & $\stackrel{0}{i}$ & ì & ì & 욜 \\
\hline & Fluoranthene & กิ่ & $\stackrel{\bullet}{i}$ & $n$ & $\tilde{v}$ & $n$ & $n$ & $\ddot{0}$ & $\hat{0}$ & $\stackrel{\leftrightarrow}{+}$ & $\ddot{n}$ & $\ddot{n}$ & $\ddot{n}$ & $\stackrel{\circ}{\sim}$ & $\stackrel{\dot{q}}{2}$ & ํㅏㅇㅇ. \\
\hline & Anthracene & $\begin{array}{ll}4 \\
0 \\
0\end{array}$ & $\stackrel{\sim}{\sim}$ & $\stackrel{\circ}{\circ}$ & $\overrightarrow{0}$ & $\overrightarrow{\dot{\theta}}$ & $\overrightarrow{\dot{\theta}}$ & ֻุ & $\hat{0}$ & $\overrightarrow{\dot{v}}$ & $\overrightarrow{\dot{v}}$ & 9 & : & $\stackrel{\circ}{=}$ & $\stackrel{\dot{H}}{i}$ & $\stackrel{1}{\circ} \stackrel{0}{=}$ \\
\hline & Phenanthrene & ก̦ & $\stackrel{\dot{m}}{\dot{m}}$ & $\stackrel{m}{\hat{v}}$ & $\stackrel{m}{\hat{v}}$ & $\stackrel{m}{\hat{v}}$ & $\stackrel{\circ}{\circ}$ & 3 & $\stackrel{m}{\hat{p}}$ & $\stackrel{m}{\hat{v}}$ & ?̧ & $\stackrel{\infty}{ \pm}$ & ? & 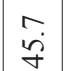 & $\stackrel{+}{\stackrel{1}{+}}$ & भi่ \\
\hline & Fluorene & $\tilde{0}$ & $\stackrel{2}{\Upsilon}$ & $\begin{array}{l}0 \\
i\end{array}$ & $\hat{i}$ & $\tilde{n}$ & $\stackrel{+}{m}$ & $\ddot{m}$ & $\ddot{m}$ & $\tilde{4}$ & in & $\bar{i}$ & $\begin{array}{l}0 \\
\infty\end{array}$ & $\begin{array}{l}\dot{0} \\
\dot{0}\end{array}$ & $\stackrel{n}{n}$ & $\begin{array}{ll}i \\
0 \\
0 \\
0\end{array}$ \\
\hline & Acenaphtene & 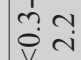 & $\ddot{n}$ & $\stackrel{+}{=}$ & $\stackrel{m}{\ominus}$ & $=$ & $\begin{array}{l}\infty \\
\stackrel{\sim}{\beth}\end{array}$ & $\vec{a}$ & $\hat{a}$ & $\stackrel{?}{?}$ & $\stackrel{\imath}{r}$ & $\stackrel{\infty}{\infty}$ & $\stackrel{\mathcal{F}}{f}$ & in & $\stackrel{\stackrel{i}{\mathrm{I}}}{\mathrm{I}}$ & 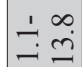 \\
\hline & Naphtalene & م. & $\begin{array}{c}0 \\
\vec{i}\end{array}$ & $\begin{array}{c}0 \\
\vec{i}\end{array}$ & $\stackrel{i}{i}$ & $\stackrel{\vec{i}}{\mathrm{i}}$ & $\stackrel{\vec{i}}{\mathrm{i}}$ & $\stackrel{\vec{i}}{\mathrm{i}}$ & $\begin{array}{c}\stackrel{\vec{i}}{v} \\
\mathrm{v}\end{array}$ & $\stackrel{i}{i}$ & $\stackrel{i}{i}$ & $\stackrel{\circ}{\dot{2}}$ & $\stackrel{\circ}{\dot{n}}$ & $\begin{array}{c}\stackrel{\dot{a}}{q} \\
\dot{q}\end{array}$ & $\stackrel{\circ}{\circ}$ & í \\
\hline & Benzo[a]pyrene & $\begin{array}{lll}1 & n \\
0 & 0 & 0\end{array}$ & $\stackrel{t}{\vec{v}}$ & ì & $\exists$ & $\begin{array}{l}\infty \\
\dot{i}\end{array}$ & $\cong$ & $\stackrel{+}{-}$ & $\begin{array}{l}\infty \\
0 \\
0\end{array}$ & $\stackrel{t}{\vec{v}}$ & $\stackrel{t}{\dot{v}}$ & 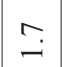 & $\stackrel{t}{\vec{v}}$ & $\stackrel{\vec{i}}{i}$ & $\stackrel{t}{\dot{v}}$ & $\begin{array}{l}\dot{1} \infty \\
\dot{0} \infty\end{array}$ \\
\hline & $\begin{array}{c}\text { Benzo[b] } \\
\text { fluoranthene }\end{array}$ & $\stackrel{m}{\nabla}$ & $\stackrel{\leftrightarrow}{\dot{V}}$ & $\stackrel{\vartheta}{i}$ & $\stackrel{?}{r}$ & $\stackrel{\varphi}{\dot{v}}$ & $\stackrel{\varphi}{\dot{V}}$ & $\stackrel{0}{\dot{V}}$ & $\begin{array}{l}0 \\
\dot{0}\end{array}$ & $\stackrel{+}{\leftrightarrows}$ & $\stackrel{0}{\dot{v}}$ & $\stackrel{\varphi}{\dot{v}}$ & $\stackrel{0}{\dot{V}}$ & $\dot{g}$ & $\begin{array}{l}0 \\
\dot{\vec{v}}\end{array}$ & bُ \\
\hline & Chrysene & 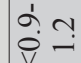 & $\stackrel{i}{i}$ & $\stackrel{i}{i}$ & $\stackrel{\circ}{i}$ & ì & ì & $\stackrel{i}{i}$ & $\begin{array}{l}0 \\
i\end{array}$ & $\stackrel{i}{i}$ & $\dot{i n}$ & $\ddot{m}$ & $\begin{array}{l}0 \\
\text { i }\end{array}$ & $\begin{array}{ll}0 \\
\infty\end{array}$ & $\stackrel{\circ}{\dot{g}}$ & di் \\
\hline & Benzo[a]anthracene & 둥 & $\tilde{\theta}$ & $\stackrel{\circ}{i}$ & $\stackrel{\Im}{I}$ & $\stackrel{3}{8}$ & $\stackrel{m}{0}$ & $\stackrel{0}{0}$ & $\stackrel{n}{0}$ & $?$ & $\overbrace{0}^{0}$ & $\stackrel{m}{\hat{v}}$ & $\stackrel{m}{\hat{v}}$ & $\stackrel{9}{9}$ & $\stackrel{\infty}{\infty}$ & ஸ் \\
\hline & 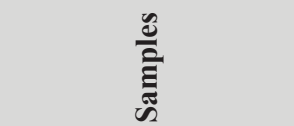 & $\mathscr{E}_{0}$ & $\vec{a}$ & $\approx$ & $\hat{2}$ & \pm & $\approx$ & : & $\hat{a}$ & $\stackrel{\infty}{2}$ & $a$ & $\frac{0}{2}$ & $\overrightarrow{\vec{a}}$ & $\frac{1}{2}$ & $\frac{m}{2}$ & 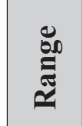 \\
\hline
\end{tabular}


Serbian (30) bee pollen (0.078-0.965 $\mathrm{mg} \mathrm{kg}^{-1}$ and 0.169 $0.465 \mathrm{mg} \mathrm{kg}^{-1}$, respectively).

As bee pollen is considered a valuable apitherapeutic product (31), its safety is very important and requires further investigation of metal contaminants in pollen from urban sites.
Table 2 also shows metal content in the samples of nectar collected in April and June 2016. Levels of metals in nectar samples were quite scattered, more or less similar to honey samples taken in the same period. This could be explained by the fact that bees visit different plants and use different plant exudates during the production of honey.

Table 4 The overview of pesticides analysed in the honey and bee pollen samples

\begin{tabular}{|c|c|}
\hline Chemical class of pesticides analysed (chemical name) & $\begin{array}{c}\text { No. of } \\
\text { pesticides }\end{array}$ \\
\hline 2,6-Dinitroaniline (pendimethalin, trifluralin) & 2 \\
\hline Amine (diphenylamine) & 1 \\
\hline Anilide (fenhexamid) & 1 \\
\hline Benzimidazole (thiabendazole) & 1 \\
\hline $\begin{array}{l}\text { Carbamate, N-methyl carbamate and thiocarbamate (carbaryl, carbofuran, chlorpropham, } \\
\text { iprovalicarb, propamocarb, methiocarb, methomyl, oxamyl, pirimicarb, propoxur, thiobencarb) }\end{array}$ & 11 \\
\hline Carboxamide (boscalid) & 1 \\
\hline Chitin synthesis inhibitors (buprofezin) & 1 \\
\hline Chloroacetanilide (alachlor, metolachlor) & 2 \\
\hline $\begin{array}{l}\text { Conazole (difenoconazole, epoxiconazole, fluquinconazole, flutriafol, imazalil, myclobutanil, } \\
\text { penconazole, prochloraz, propiconazole, prothioconazole-desthio, triadimefon, triadimenol) }\end{array}$ & 12 \\
\hline Cyclodiene (cis-chlordane, trans-chlordane, chordecone) & 3 \\
\hline Dicarboximid (procymidone) & 1 \\
\hline Dicarboximide (iprodione, vinclozolin) & 2 \\
\hline Imidazole (fenamidone) & 1 \\
\hline $\begin{array}{l}\text { Juvenile hormone mimic (pyriproxyfen) and other carbamate/juvenile hormone mimic } \\
\text { (fenoxycarb) }\end{array}$ & 2 \\
\hline Keto-enol (spiromesifen) & 1 \\
\hline Methoxyacrylate (azoxystrobin) & 1 \\
\hline Morpholine (dimethomorph) & 1 \\
\hline $\begin{array}{l}\text { Organochlorine (aldrin, p,p'-DDD, p,p'-DDE, p,p`-DDD, dieldrin, endosulfansulfate, } \\
\text { alpha-endosulfan, beta-endosulfan, endrin, keto-endrin, alpha-HCH, beta-HCH, delta-HCH, } \\
\text { gamma-HCH, heptachlor, cis-heptachlorepoxid, trans-heptachlorepoxid, hexachlorobenzene, } \\
\text { methoxychlor, oxychlordane) }\end{array}$ & 20 \\
\hline $\begin{array}{l}\text { Organophosphorus (chlorpyrifos, chlorpyrifos-methyl, coumaphos, dichlorvos, dimethoate / } \\
\text { omethoate, ethoprophos, etrimfos, famphur, fenitrothion, fensulfothion, fenthion, isocarbophos, } \\
\text { malathion, methacrifos, mevinphos, parathion, parathion-methyl, phosphamidon, pirimiphos- } \\
\text { methyl) }\end{array}$ & 20 \\
\hline Organothiophosphate (diazinon) & 1 \\
\hline Phenol (orthophenylphenol) & 1 \\
\hline Phenylsulfamide (dichlofluanid) & 1 \\
\hline Pyrazole (fipronil, tebufenpyrad) & 2 \\
\hline $\begin{array}{l}\text { Pyrethroid (bifenthrin, bioallethrin, cyfluthrin, lambda-cyhalothrin, cypermethrin, deltamethrin, } \\
\text { fenvaletate / esfenvalerate, fenpropathrin, permethrin, tefluthrin, tetramethrin) }\end{array}$ & 12 \\
\hline Pyrimidine (bupirimate, cyprodinil, mepanipyrim, pyrimethanil) & 4 \\
\hline Quinoline (ethoxyquin, quinoxyfen) & 2 \\
\hline Strobin (kresoxim-methyl, trifloxystrobin) & 2 \\
\hline Triazine (cyanazine, prometon, prometryn, propazine, simazine, terbuthylazine) & 6 \\
\hline Triazinone (hexazinone, metribuzin) & 2 \\
\hline Unclassified (biphenyl, fenazaquin, fenpropidin, propargite) & 4 \\
\hline Uracil (bromacil) & 1 \\
\hline Xylylalanine (metalaxyl) & 1 \\
\hline
\end{tabular}


Besides, even the bees from same apiary may visit sites with different levels of contamination (32).

\section{Content of polycyclic aromatic hydrocarbons}

Table 3 shows PAH content in the honey and pollen samples. Sums of all 15 PAHs in honey ranged from 2.8 $18.1 \mu \mathrm{g} \mathrm{kg}^{-1}$. Our benzo[a]pyrene levels in honey correspond to those reported in the studies of Czech (33) and Polish honey (34). It is interesting that the sum of benzo[a] anthracene, chrysene, benzo[b]fluoranthene, and benzo[a] pyrene in French honey taken from non-urban sites (0.03$5.80 \mu \mathrm{g} \mathrm{kg}^{-1}$ ) was higher than the sum of these PAHs in our samples (35).

The content of other PAHs, such as chrysene, phenantrene, and anthracene in our honey samples were similar to those in Italian honey samples originating from polluted areas (36).

Naphthalene had the highest concentrations in the honey samples $\left(<0.8-11.6 \mu \mathrm{g} \mathrm{kg}^{-1}\right)$, but they were much lower than, for example, those reported by Dobrinas et al. (37) (up to $665.0 \mu \mathrm{g} \mathrm{kg}^{-1}$ ) in honey from Romanian urban areas (37).

The sums of the 15 analysed PAHs in pollen ranged from 6.4 to $163.3 \mu \mathrm{g} \mathrm{kg}^{-1}$. The sum of benzo[a]anthracene, chrysene, benzo[b]fluoranthene, and benzo[a]pyrene was lower than reported for French pollen $\left(0.22-129.41 \mu \mathrm{g} \mathrm{kg}^{-1}\right)$ from non-urban sites (35).

The highest levels in the pollen samples were those of phenanthrene, naphthalene, and indeno[1,2,3-cd]pyrene; their ranges were $<0.3-74.2 \mu \mathrm{g} \mathrm{kg}^{-1},<2.0-51.0 \mu \mathrm{g} \mathrm{kg}^{-1}$, and $<0.4-$ $41.4 \mu \mathrm{g} \mathrm{kg}^{-1}$, respectively. Naphthalene was higher in all three pollen samples from $2016\left(39.0-51.0 \mu \mathrm{g} \mathrm{kg}^{-1}\right)$ than in those from $2015\left(<0.2 \mu \mathrm{g} \mathrm{kg}^{-1}\right)$. Similar was for phenantrene (74.2 $\mu \mathrm{g} \mathrm{kg}^{-1}$ vs. $45.7 \mu \mathrm{g} \mathrm{kg}^{-1}$, respectively). This could be attributed to air pollution by traffic and fossil fuel heating, as well as weather conditions favouring the distribution of PAHs (36).

As expected, the PAH levels in pollen were higher than in honey, because they are highly lipophilic, and pollen contains $4-8 \%$ of lipids, in some cases even $22.4 \%$ (30, $38,39)$, while honey contains none. It is mainly composed of sugars, amino acids, organic acids, minerals, and other relatively hydrophilic constituents (40).

\section{Pesticide content}

Table 4 shows how many honey and bee pollen samples showed the presence of one or more of the 123 pesticides analysed by GC-MS. However, none of the detected pesticide residues went above the LOQ of the method $\left(0.01 \mathrm{mg} \mathrm{kg}^{-1}\right)$.

There are not many data about the presence of pesticides in honey and other bee products from exclusively urban sites $(41,42)$. Lambert et al. (43) reported higher, but not significantly higher contamination of rural honey than honey from other landscapes, including urban (43).

\section{CONCLUSION}

To the best of our knowledge, this is the first more comprehensive report on the safety aspects of urban honey, pollen, and nectar in terms of toxic metals, PAHs, and pesticide residues.

Our honey samples met the European and Serbian regulations for pesticides and metals $(\mathrm{Pb}, \mathrm{Cd}, \mathrm{As}, \mathrm{Cu}, \mathrm{Zn}$, and $\mathrm{Fe}$ ). Our results suggest that the city environment does not pose greater risk of honey contamination if good beekeeping practices are followed. Pollen contamination needs further investigation, especially of air pollutants, as is indicated by elevated levels of $\mathrm{Hg}, \mathrm{Cr}$, and PAHs.

We believe that our findings will encourage the development of urban beekeeping with its undeniable benefits for urban residents and the environment.

\section{Acknowledgement}

This work was supported by the Ministry of Education, Science and Technological Development of Serbia (grant Nos. 172017 and 46008).

\section{REFERENCES}

1. Maeterlinck M. The life of the Bee. New York: Dodd, Mead; 1901.

2. Devillers J. The ecological importance of honey bees and their relevance to ecotoxicology. In: Devillers J, PhamDelègue $\mathrm{M}$, editors. Honey bees: estimating the environmental impact of chemicals. $1^{\text {st }}$ ed. London and New York (NY): Taylor \& Francis e-Library; 2003. p. 1-12.

3. Ruschioni S, Riolo P, Minuz RL, Stefano M, Cannella M, Porrini C, Isidoro N. Biomonitoring with honeybees of heavy metals and pesticides in nature reserves of the Marche Region (Italy). Biol Trace Elem Res 2013;154:226-33. doi: 10.1007/ s12011-013-9732-6

4. Zarić NM, Ilijević K, Stanisavljević Lj, Gržetić I. Use of honeybees (Apis mellifera $\mathrm{L}$.) as bioindicators for assessment and source appointment of metal pollution. Environ Sci Pollut Res Int 2017;24:25828-38. doi: 10.1007/s11356-017-0196-7

5. Bargańska Ż, Ślebioda M, Namieśnik J. Honey bees and their products: Bioindicators of environmental contamination. Crit Rev Environ Sci Technol 2015;46:235-48. doi: 10.1080/10643389. 2015.1078220

6. Bogdanov S. Contaminants of bee products. Apidologie 2006;37:1-18. doi: 10.1051/apido:2005043

7. Al-Waili N, Salom K, Al-Ghamdi A, Ansari MJ. Antibiotic, pesticide, and microbial contaminants of honey: human health hazards. ScientificWorldJo 2012;2012:930849. doi: 10.1100/2012/930849

8. Sitarz-Palczak E, Kalembkiewicz J, Galas D. Evaluation of the content of selected heavy metals in samples of Polish honeys. J Ecol Eng 2015;16:130-8. doi: 10.12911/22998993/ 2946

9. European Food Safety Authority (EFSA). Bee health [displayed 29 June 2017]. Available at http://www.efsa. europa.eu/en/topics/topic/bee-health 
10. Greenpeace. The global and European situation with bees and other pollinators [displayed 29 June 2017]. Available at http://sos-bees.org/situation/

11. European Food Safety Authority (EFSA). Scientific report submitted to EFSA Bee Mortality and Bee Surveillance in Europe. CFP/EFSA/AMU/2008/02. Accepted for Publication on 03 December 2009 [displayed 29 June 2017]. Available at https://efsa.onlinelibrary.wiley.com/doi/pdf/10.2903/sp. efsa.2009.EN-27

12. European Environment Agency (EEA). Article the Environmental Atlas City bees, 2010 [displayed 18 April 2016]. Available at http://www.eea.europa.eu/atlas/eea/citybees/story/article

13. European Environment Agency (EEA). EEA's bees project. Making Copenhagen buzz, 2012 [displayed 10 November 2016]. Available at http://www.eea.europa.eu/about-us/what/ eeas-bees-project

14. Regulation (EC) No 396/2005 of the European Parliament and of the Council of 23 February 2005 on maximum residue levels of pesticides in or on food and feed of plant and animal origin and amending Council Directive 91/414/EEC Text with EEA relevance [displayed 11 July 2018]. Available at https://eur-lex.europa.eu/legal-content/EN/TXT/ $\mathrm{PDF} /$ ?uri=CELEX:32005R0396\& from=EN

15. Commission Regulation (EU) No 37/2010 of 22 December 2009 on pharmacologically active substances and their classification regarding maximum residue limits in foodstuffs of animal origin (Text with EEA relevance) [displayed 11 July 2018]. Available at https://eur-lex.europa.eu/legalcontent/EN/TXT/PDF/?uri=CELEX:32010R0037\& from $=\mathrm{EN}$

16. Pravilnik o maksimalno dozvoljenim količinama ostataka sredstava za zaštitu bilja u hrani i hrani za životinje i o hrani i hrani za životinje za koju se utvrđuju maksimalno dozvoljene količine ostataka sredstava za zaštitu bilja [Regulation on maximum residue levels of plant protection products in food and feed and on food and feed for which the maximum residue levels of plant protection products are set, in Serbian]. RS Official Gazette No. 29/2014.

17. Commission Regulation (EU) 2015/1005 amending Regulation (EC) No 1881/2006 as regards maximum levels of lead in certain (Text with EEA relevance) [displayed 11 July 2018]. Available at https://eur-lex.europa.eu/legalcontent/EN/TXT/PDF/?uri=CELEX:32015R1005\& from $=\mathrm{EN}$

18. Jovetić M, Trifković J, Stanković D, Manojlović D, Milojković-Opsenica D. Mineral content as a tool for the assessment of honey authenticity. J AOAC Int 2017;100:86270. doi: 10.5740/jaoacint.17-0145

19. Regulation (EC) No $1935 / 2004$ of the European Parliament and of the Council of 27 October 2004 on materials and articles intended to come into contact with food and repealing Directives 80/590/EEC and 89/109/EEC [displayed 22 September 2018]. Available at https://eur-lex.europa.eu/ legal-content/EN/TXT/PDF/?uri=CELEX:32004R1935\& from $=\mathrm{EN}$

20. Commission Regulation (EU) No 10/2011 of 14 January 2011 on plastic materials and articles intended to come into contact with food (Text with EEA relevance) [displayed 22 September 2018]. Available at https://eur-lex.europa.eu/ legal-content/EN/TXT/PDF/?uri=CELEX:32011R0010\& from $=\mathrm{EN}$
21. International Honey Commission (IHC). Harmonised methods of the International Honey Commission 2009 [displayed 11 July 2018]. Available at http://www.ihcplatform.net/ihcmethods2009.pdf

22. Matović K, Ćirić J, Kaljević V, Nedić N, Jevtić G, Vasković $\mathrm{N}$, Baltić MŽ. Physicochemical parameters and microbiological status of honey produced in an urban environment in Serbia. Environ Sci Pollut Res Int 2018;25:14148-57. doi: 10.1007/s11356-018-1659-1

23. Bilandžić N, Sedak M, Đokić M, Solomun Kolanović B, Varenina I, Božić Đ, Šimić B, Končurat A, Brstilo M. Lead content in multifloral honey from central Croatia over a three-year period. Bull Environ Contam Toxicol 2012;88:9859. doi: 10.1007/s00128-012-0585-Z

24. Bilandžić N, Đokić M, Sedak M, Solomun Kolanović B, Varenina I, Končurat A, Rudan N. Determination of trace elements in Croatian floral honey originating from different regions. Food Chem 2011;128:1160-4. doi: 10.1016/j. foodchem.2011.04.023

25. Oroian M, Amariei S, Leahu A, Gutt G. Multi-element composition of honey as a suitable tool for its authenticity analysis. Pol J Food Nutr Sci 2015;65:93-100. doi: 10.1515/ pjfns-2015-0018

26. Toporcák J, Legáth J, Kul'ková J. [Levels of mercury in samples of bees and honey from areas with and without industrial contamination, in Slovak]. Vet Med (Praha) 1992;37:405-12. PMID: 1413402

27. Toth T, Kopernicka M, Sabo R, Kopernicka T. The evaluation of mercury in honey bees and their products from eastern Slovakia. Scientific Papers Anim Sci Biotechnol 2016;49:25760.

28. Maragou NC, Pavlidis G, Karasali H, Hatjina F. Cold vapor atomic absorption and microwave digestion for the determination of mercury in honey, pollen, propolis and bees of Greek origin. Global NEST J 2016;18:690-6.

29. Roman A, Popiela-Pleban E, Migdał P, Kruszyński W. As, $\mathrm{Cr}, \mathrm{Cd}$, and $\mathrm{Pb}$ in bee products from a Polish industrialized region. Open Chem 2016;14:33-6. doi: 10.1515/chem-20160007

30. Kostić A, Pešić M, Mosić M, Dojčinović B, Natić M, Trifković J. Mineral content of bee pollen from Serbia. Arh Hig Rada Toksikol 2015;66:251-8. doi: 10.1515/aiht-201566-2630

31. Komosinska-Vassev K, Olczyk P, Kaźmierczak J, Mencner L, Olczyk K. Bee pollen: chemical composition and therapeutic application. Evid-Based Compl Alt 2015;2015:297425. doi: 10.1155/2015/297425

32. Jacquemyn H, Lenaerts M, Brys R, Willems K, Honnay O, Lievens B. Among-population variation in microbial community structure in the floral nectar of the bee-pollinated forest herb Pulmonaria officinalis L. PLoS One 2013;8(3):e56917. doi: 10.1371/journal.pone.0056917

33. Batelkova P, Borkovcová I, Čelechovská O, Vorlová L, Bartáková K. Polycyclic aromatic hydrocarbons and risk elements in honey from the South Moravian region (Czech Republic). Acta Vet Brno 2012;81:169-74. doi: 10.2754/ avb201281020169

34. Ciemniak A, Witczak A, Mocek K. Assessment of honey contamination with polycyclic aromatic hydrocarbons. J Env Sci Health B 2013;48:993-8. doi: 10.1080/03601234. 2013.816609 
35. Lambert O, Veyrand B, Durand S, Marchand P, Le Bizec B, Piroux M, Puyo S, Thorin C, Delbac F, Poulquen H. Polycyclic aromatic hydrocarbons: Bees, honey and pollen as sentinels for environmental chemical contaminants. Chemosphere 2012;86:98-104. doi: 10.1016/j.chemosphere. 2011.09.025

36. Perugini M, Di Serafino G, Giacomelli A, Medrzycki P, Sabatini AG, Persano Oddo L, Marinelli E, Amorena M. Monitoring of polycyclic aromatic hydrocarbons in bees (Apis mellifera) and honey in urban areas and wildlife reserves. J Agr Food Chem 2009;57:7440-4. doi: 10.1021/ jf9011054

37. Dobrinas S, Birghila S, Coatu V. Assessment of polycyclic aromatic hydrocarbons in honey and propolis produced from various flowering trees and plants in Romania. J Food Compos Anal 2008;21:71-7. doi: 10.1016/j.jfca.2007.07.003

38. Szczesna T. Long-chain fatty acids composition of honeybeecollected pollen. J Apic Sci 2006;50:65-79.

39. World Health Organization (WHO). Polycyclic aromatic hydrocarbons. Chapter 5.9. In: Air quality guidelines for
Euope. $2^{\text {nd }}$ ed. WHO Regional Publications European Series No. 91. Copenhagen: WHO; 2000. p. 92-6.

40. da Silva PM, Gauche C, Gonzaga LV, Costa ACO, Fett R. Honey: Chemical composition, stability and authenticity. Food Chem 2016;196:309-23. doi: 10.1016/j. foodchem.2015.09.051

41. Chauzat MP, Faucon JP, Martel AC, Lachaize J, Cougoule $\mathrm{N}$, Aubert M. A survey of pesticide residues in pollen loads collected by honey bees in France. J Econ Entomol 2006;99:253-62. doi: 10.1603/0022-0493-99.2.253

42. Mullin CA, Frazier M, Frazier JL, Ashcraft S, Simonds R, van Engelsdorp D, Pettis JS. High levels of miticides and agrochemicals in North American apiaries: Implications for honey bee health. PLoS One 2010;5(3):e9754. doi: 10.1371/ journal.pone. 0009754

43. Lambert O, Piroux M, Puyo S, Thorin C, L'HostisM, Wiest L, Buleté A, Delbac F, Pouliquen H. Widespread occurrence of chemical residues in beehive matrices from apiaries located in different landscapes of Western France. PLoS One 2013;8(6):e67007. doi: 10.1371/journal.pone.0067007

\section{Zagađivala u pčelinjim proizvodima urbanog podrijetla}

Glavni cilj ove studije, kao doprinosa razvoju koncepta urbanog pčelarstva, bio je dati informacije o određenim zagađivalima - toksičnim metalima, policikličkim aromatskim ugljikovodicima (PAHs) i pesticidima koji bi mogli biti prisutni u pčelinjim proizvodima (med i pelud) isključivo urbanog podrijetla. Uzorci meda (23), peludi (13) i cvjetnog nektara (6) iz 2015. i 2016. godine dobiveni su iz eksperimentalnog stacionarnog pčelinjaka Poljoprivrednog fakulteta u središtu Zemuna (Beograd). Sadržaj metala (Pb, Cd, As, Cu, Zn, Fe, Mn, Ni, Cr i Hg) određen je pomoću induktivno spregnute plazme kvadrupolske masene spektrometrije (ICP-QMS). Policiklički aromatski ugljikovodici analizirani su tekućinskom kromatografijom visokog učinka uz fluorescentnu detekciju (HPLC-FLD). Pesticidi su analizirani plinskom kromatografijom s masenom spektrometrijom (GC-MS). Uzorci meda ispunjavali su europske i srbijanske službene propise vezane za najveće dopuštene količine određenih metala. Koncentracija 123 analizirana pesticida bila je ispod granice kvantifikacije (LOQ). Što se tiče sadržaja PAH u medu, najveća koncentracija pronađena je za naftalen. Povišene vrijednosti za neke metale $(\mathrm{Hg}, \mathrm{Cr})$ i PAH u uzorcima peludi upozoravaju na onečišćenje zraka kojem je pelud izložen. Što se tiče ostataka pesticida u peludi, oni su bili ispod LOQ-a. Sadržaj metala u nektaru bio je do određene mjere sličan onomu u medu. Općenito se može zaključiti da je ispitani med s urbanoga područja u pogledu sadržaja metala, PAH i pesticida u skladu s europskim i srbijanskim propisima. 